\title{
Human immunodeficiency virus infection in voluntary blood donors in North-Eastern Nigeria
}

\author{
${ }^{1}$ Olokoba A.B., ${ }^{2}$ Tidi S.K., ${ }^{2}$ Salawu F.K., ${ }^{2}$ Danburam A, ${ }^{1}$ Desalu O.O., ${ }^{3}$ Abdulrahman M.B., \\ ${ }^{4}$ Babalola O.M., ${ }^{5}$ Olokoba L.B., ${ }^{2}$ Midala J, ${ }^{2}$ Badung L.H. \\ ${ }^{1}$ Department of Medicine, ${ }^{3}$ Department of Chemical Pathology, ${ }^{4}$ Department of Surgery, \\ ${ }^{5}$ Department of Ophthalmology, University of Ilorin Teaching Hospital, Ilorin, Nigeria. \\ ${ }^{2}$ Federal Medical Centre, Yola, Nigeria. \\ All Correspondence to: Dr Olokoba A.B FWACP,DTMH(London), MPH, MBA, \\ Gastroenterology Unit, Department of Medicine, University of Ilorin Teaching Hospital, P.M.B \\ 1459, Ilorin. Kwara State, Nigeria.Email: drabolokoba@yahoo.com
}

\begin{abstract}
The Human immunodeficiency virus infection is known to occur in the general population, and due to their mode of transmission through blood and blood products, it has made the provision of safe blood increasingly difficult, and the screening of blood absolutely necessary. The objective was to determine the sero-prevalence of Human immunodeficiency virus infection among voluntary blood donors. It was a hospital-based cross sectional study. Place of study was the Blood bank of Federal Medical Centre, Yola, Nigeria from January, 2007 to December, 2008. Five hundred and ninety five consecutively recruited voluntary blood donors were screened for Human immunodeficiency virus infection. The HIV serology was determined by enzyme-linked immunesorbent assay (GENSCREEN plus HIV Ag Ab BIO RAD, France) and confirmed by Immunocomb assay II (HIV 1 and HIV 2 CombFirm test Orgenics Israel). The biodata of the patients were obtained. Written informed consent was obtained from each patient. A total of 595 donors were screened. 571 donors (96\%) were males while $24(4 \%)$ were females. The mean age was $31.3+/-7.9$ years. Only the male donors had HIV infection. Only 4 donors $(0.7 \%)$ were positive for HIV infection. The conclusion is that the sero-prevalence of HIV infection is low among voluntary blood donors in North-eastern Nigeria.
\end{abstract}

Keywords: human immunodeficiency virus, blood donors, Nigeria

\section{INTRODUCTION}

Human immunodeficiency virus (HIV), the causative agent of Acquired immunodeficiency syndrome (AIDS) is found in pandemic proportions globally (Osmond and Dennis, 1994). HIV is a scourge, progressing and causing devastation to lives and the healthcare system worldwide (Carpenter et al, 2000). HIV accounted for 38.6 million infections worldwide at the end of 2005. As at 2003, there were about 5.0 million people infected with HIV in Nigeria, giving a national prevalence rate of $5.0 \%$ (Federal Ministry of Health, 2004). Infection with HIV occurs by the transfer of blood, semen, vaginal fluid, pre-ejaculate, or breast milk. The four major routes of transmission are unprotected sexual intercourse, contaminated needles, breast milk, transmission from an infected mother to her baby at birth (vertical transmission) (http://en.wikipedia.org/wiki/HIV).
Millions of lives are saved each year through blood transfusion. Nonetheless people have a risk of becoming infected with HIV through transfusion of blood and blood products. We therefore investigated the risk of HIV infection through blood transfusion in North-eastern Nigeria.

MATERIALS AND METHODS The serum samples of all consecutively recruited voluntary blood donors were screened for HIV infection. The HIV serology was determined by enzyme-linked immune-sorbent assay (GENSCREEN plus HIV Ag Ab BIO RAD, France) and confirmed by Immunocomb assay II (HIV 1 and HIV 2 CombFirm test Orgenics Israel).

Their bio-data was obtained. Written informed consent was obtained from each patient.

The study was approved by the Ethics and Research committee of the Federal Medical Centre, Yola, Nigeria. 
Analysis: The data obtained were analysed using the statistical package for social sciences (SPSS, version 10.0) statistical software.

\section{RESULTS}

At the conclusion of the study, a total of five hundred and ninety-five voluntary blood donors were found to have been screened for HIV infections. Only the male donors had HIV infection

\section{Demographic data of the donors}

Age: The age of the donors ranged from 18-61years with a mean of $31.3+/-7.9$ years. Majority of the donors were in the age group 20-29years ie third decade of life. (Table 1)

Sex: Five hundred and seventy-one donors were males (96.0\%) while twenty-four were females (4.0\%) giving a male to female ratio of 23.8:1 (Table 2).

Frequency of HIV infection: Four donors (0.7\%) were positive for HIV infection (Table 1).

Occupation of blood donors with HIV infection: Two donors (50.0\%) with HIV infection were civil servants, while one donor (25.0\%) each was a businessman, and a farmer (Table 3).

\section{DISCUSSION}

Our study was aimed at determining the seroprevalence of HIV infection among voluntary blood donors. The literature also notes that this transfusiontransmissible viral infection can occur in blood donors (Khan et al, 2002). From this study, the age range of blood donors was 18 to 61 years with a mean of 31.3 years. This is similar to that in the study of Khan et al (2002) who found that their blood donors were in the age range of 18 to 60 years. It is also similar to the findings of Muktar et al(2005) in Zaria, North-western, Nigeria in which their donors had a mean age of 33 years even though their age ranged from 19 to 42 years. However the donors in Jos, North-central, Nigeria were in the age range 21 to 50 years according to Egah et al(2004)

Most of the blood donors in this study were males, $96 \%$. This is similar to the $95 \%$ in the study of Egah et al(2004). Muktar et al(2005) found that $98 \%$ of their donors were males while Nwokediuko et al(2007) in their study in Enugu, South-eastern, Nigeria found that $91.8 \%$ of their donors were males. However all the donors were males in the study of Elfaki et al(2008) among Sudanese donors, and the study of Khan et al(2002).
From this study, HIV infection among blood donors was $0.7 \%$. This figure is higher than the $0.08 \%$ found by Gupta et al (2004) in their study among Indian blood donors. It is also much higher than the $0.004 \%$ found by Bhatti et al (2007) in Karachi among Pakistani donors, and the $0.00009 \%$ found by Khan et al (2002) in Peshawar among Pakistani donors.

The HIV infection rate in this study is however lower than $1.0 \%$ in the work of Ejele et al (2005) in Port Harcourt, South-south Nigeria; the 3.1\% found by Fiekumo et al (2009) in Osogbo, South-west Nigeria; the $3.9 \%$ found by Esumeh et al (2003) in another study in Benin city, South-south Nigeria; the 5.8\% in the works of Chikwem et al (1997) in Maiduguri, North-eastern Nigeria and that of Abdalla et al (2005) among Kenyan donors.

Furthermore, Fasola et al (2009) found an infection rate of $7.7 \%$ among their donors in Ibadan, Southwestern Nigeria while Matee et al (1999) in their work among Tanzanian donors, and Kagu et al (2005) in their work in Nguru, North-eastern Nigeria found an HIV infection rate of $8.7 \%$.

The wide differences in the HIV infection rate among the blood donors in the different regions within Nigeria, and even those outside Nigeria may be due to the differences in geographical locations, age range of donor patients, sample sizes, the period of time the studies were carried out, and the different socio-cultural practices such as sexual behavior, marriage practices, circumcision, scarification, tattooing etc which take place in these regions. Access to healthcare services, and the laboratory test reagents used may also be contributory factors.

The implication of HIV in voluntary blood donors is the risk of transmission of these infections to recipients of blood and blood products. It also implies that safe blood will be more difficult to get.

An unsafe blood transfusion is very costly both in terms of human and economic costs. Morbidity and mortality resulting from the transfusion of infected blood have far-reaching consequences, not only for the recipients themselves, but also their families, their communities and the wider society (WHO, 2002 and 2007). Since a person can transmit HIV infection during the asymptomatic phase, it can contribute to an ever-widening pool of HIV infection in the wider population.

From this study, it is observed that HIV infection was found among the 20-39 years age range. This finding is in agreement with the study by Ejele et al(2005) in 
which higher prevalence of transfusion-transmissible viral infections was observed among youths. This observation is worrisome since the most productive and economically viable age group of the populations is worst hit. There is the urgent need for renewed intensification of preventive programmes aimed at high risk behavioural change.

We recommend the screening of all prospective blood donors for all transfusion transmissible

Table 1. Age groups and HIV infection

\begin{tabular}{|c|c|c|c|}
\hline $\begin{array}{l}\text { Age groups (Years) } \\
\text { positive (n) }(\%)\end{array}$ & \multicolumn{2}{|c|}{ Frequency (n) (\%) } & HIV \\
\hline$<20$ & 15 & (2.5) & - \\
\hline $20-29$ & 265 & (44.5) & $2(50.0)$ \\
\hline $30-39$ & 231 & (38.8) & $2(50.0)$ \\
\hline $40-49$ & 66 & (11.1) & - \\
\hline $50-59$ & 15 & $(2.5)$ & - \\
\hline $60-69$ & 3 & $(0.5)$ & - \\
\hline Total & 595 & (100.0) & $4(100.0)$ \\
\hline Sex & Freque & cy & Percent \\
\hline Male & 571 & & 96.0 \\
\hline Female & 24 & & 4.0 \\
\hline Total & 595 & & 100 \\
\hline
\end{tabular}

Table 3. Occupation versus HIV infection Occupation $\quad$ Frequency (n) (\%) HIV (n) (\%)

$\begin{array}{lcc}\text { Unemployed } & 13(2.2) & - \\ \text { Business man } & 130(21.8) & 1(25.0) \\ \text { Civil servant } & 217(36.5) & 2(50.0) \\ \text { Carpenter } & 1(0.2) & - \\ \text { Clergyman } & 1(0.2) & - \\ \text { Youth corper } & 2(0.3) & - \\ \text { Driver } & 16(2.7) & - \\ \text { Farmer } & 46(7.7) & 1(25.0) \\ \text { Housewife } & 6(1.0) & - \\ \text { Labourer } & 3(0.5) & - \\ \text { Meat butcher } & 1(0.2) & - \\ \text { Student } & 151(25.4) & - \\ \text { Tailor } & 2(0.3) & - \\ \text { Teacher } & 1(0.2) & - \\ \text { Trader } & 5(0.8) & 4(100.0) \\ \text { Total } & 595(100.0) & \end{array}$

infections. A strict selection criteria for blood donors to exclude those who have multiple sexual partners and those who engage in high risk behaviour, and that blood transfusion should be restricted.

\section{CONCLUSION}

Even though the sero-prevalence of HIV infection is low among voluntary blood donors in North-eastern, Nigeria, safe blood will be more difficult to get.

\section{REFERENCES}

Abdalla F, Mwanda OW, Rana F (2005). Comparing walk-in and call-responsive donors in a national and a private hospital in Nairobi. East African Medical Journal. 82(10):532-536.

Bhatti FA, Ullah Z, Salamat N, Ayub M, Ghani E (2007). Anti-hepatitis $B$ core antigen testing, viral markers, and occult hepatitis B virus infection in Pakistani blood donors: implication for transfusion practice. Transfusion. 47(1):74-79.

Carpenter CC, Cooper DA, Fischi MA et al (2000). Antiretroviral therapy update and recommendation of the international AIDS society- USA panel. JAMA .28(3):381-390.

Chikwem J.O., I. Mohammed, G.C. Okara, N.C. Ukwandu, T.O. Ola (1997). Prevalence of transmissible blood infections among blood donors at the University of Maiduguri Teaching Hospital, Maiduguri, Nigeria. East African Medical Journal. 74(4):213-216.

Egah DZ, Mandong BM, Iya D, Gomwalk NE, Audu ES, Banwat EB et al(2004). Hepatitis C virus antibodies among blood donors in Jos, Nigeria. Annals of African Medicine. 3(1):35-37.

Ejele OA, Erhabor, Nwauche CA.(2005) The risk of transfusion-transmissible viral infections in the NigerDelta area of Nigeria. Sahel Medical Journal. 8(1):1619.

Elfaki AM, Eldour AA, Elsheikh NM(2008). Seroprevalence of immunodeficiency virus, hepatitis $B$ and $C$ and syphilis among blood donors at ElObeid Teaching Hospital, West Sudan. Sudan Journal of Medical Sciences. 3(4):333-338.

Esumeh FI, Ugbomoiko D, Isibor JO (2003). Seroprevalence of HIV and Hepatitis B surface antigen (HBsAg) among blood donors in central hospital, Benin city, Nigeria. Journal of Medical Laboratory Science. 12(2):52-55.

Fasola FA, Kotila TR, Akinyemi JO (2009). Trends in transfusion-transmissible viral infections from 2001 to 2006 in Ibadan, Nigeria. Intervirology.51(6):427-431 
Federal Ministry of Health (2004). Summary of findings from 2003 National HIV seroprevalence survey in Nigeria. Information for policy makers.12-38.

Fiekumo I.B., A.M. Musa, Z.A. Jeremiah (2009). Seroepidemilogy of transfusion-transmissible infectious diseases among blood donors in Osogbo, South-west, Nigeria. Blood Transfusion.,1:1-10

Gupta N., V. Kumar, A. Kaur (2004). Seroprevalence of HIV, HBV, HCV, and syphilis in voluntary blood donors. Indian J Med Sci., 58(6): 255-256.

(http://en.wikipedia.org/wiki/HIV)

Kagu MB, Kawuwa MB, Ayilara AO, Ali BZ(2005). Seroprevalence of HIV and hepatitis viruses in directed blood donors: a preliminary report. Highland Medical Research Journal. 3(2):76-80.

Khan Z, Raziq F, Aslam N (2002). Prevalence of HIV in N.W.F.P. Journal of Postgraduate Medical Institute. 16(2):187-189.

Matee MI, Lyamuya EF, Mbena EC, Magessa PM, Sufi J, Marwa GJ et al(1997). Prevalence of transfusionassociated viral infections and syphilis among blood donors in Muhimbili Medical Centre, Dar es Salaam, Tanzania. East Afr Med J. 76(3):167-171.

Muktar HM, Suleiman AM, Jones M (2005). Safety of blood transfusion: prevalence of hepatitis B surface antigen in blood donors in Zaria, Northern Nigeria. Nigerian journal of Surgical Research.7(3\&4): 290-292.

Nwokediuko SC, Ibegbulam OG, Ugwu T (2007). Hepatitis $C$ virus seroprevalence in blood donors at the University of Nigeria Teaching Hospital, Enugu. Journal of College of Medicine. 12(2):85-88.

Osmond M, Dennis H (1994). Classification and staging of HIV disease, In The AIDS knowledge base. $2^{\text {nd }}$ Ed. Cohen PT, Sande MA, Volberding PA(eds). New York: Little Brown.

World Health Organization (2002). Blood Safety Strategy for the African Region. Brazzaville, World Health Organization, Regional Office for Africa (WHO AFR /RC51/9 Rev.1).

World Health Organization (2007). Status of blood safety in the WHO African Region: Report of the 2004 Survey WHO Regional Office for Africa, Brazzaville .1-25 